\title{
Plates and figures
}

\section{Plates}

I Yu Feng Nan Fu Xuanshan Miao

2 Oil wok ritual

3 Tua Ya Pek splices his tongue

4 Cemetery plot for foetuses, babies and young children

5 Offerings before the foetus ghost's altar

6 Guan Gong paying respects to a Datuk Gong, Malaysia

7 The 'Hell of Severing in Two'

8 Ah Boon resting in Di Ya Pek's altar room

9 Di Ya Pek and luk thep dolls

Io Dasheng Gong Chenghuang Dian's Underworld altar

I I One pair of Tua Di Ya Pek at the conference

I2 My coffin ritual at Brickfields Chenghuangmiao

I3 Miniature coffins frequently found on Singapore's Underworld altars

I4 Anxi Chenghuangmiao's Tua Di Ya Pek (top) compared to their common depiction in Singapore and Malaysia (bottom)

Is Inviting the temple's deities at Anxi Chenghuangmiao

I6 Feeding Tua Ya Pek opium at Penang's City God Temple

\section{Figures}

5.I Bao Bei Ya in Geylang

5.2 Tua Ya Pek at Sanzhong Gong

6.I Central to the foetus ghost's altar

6.2 Tua Ya Pek preparing to cast coins

6.3 Pierced with skewers representing the Eight Underworld Generals 100

7.I The Third Court of King Songdi

7.2 Tua Di Ya Pek dancing

8.I Dizangwang's 'huashen'

8.2 Tua Di Ya Pek's wardrobe

9.I The prison cell

9.2 Di Ya Pek patrolling the area 
viii PLATES AND FIGURES

Io.I Ba Ye Gong (Xie Bian) and Jiu Ye Gong’s (Fan Wujiu’s) new graves

I0.2 The lowest section of the new staircase

I I. I Underworld throne in Penang

All images in this book are the property of the author. 